\title{
HUBUNGAN ANTARA KEBIASAAN MENGGUNAKAN MASKER DENGAN TERJADINYA BATUK PADA PEKERJA INDUSTRI MEBEL DI DESA KARANGSONO KECAMATAN SUKOREJO KABUPATEN PASURUAN
}

\section{Correlation Between Habitual of Wearing Mask With Cough Incidence To The Workers At The Furniture Industry In Karangsono Village Sukorejo, Pasuruan}

\author{
Marsaid $^{1}$, Hurun Ain ${ }^{2}$, Nurul Hidayah ${ }^{3}$ \\ ${ }^{1,2,3)}$ Program Studi Keperawatan Lawang Poltekkes Kemenkes Malang \\ Jl. A. Yani No 1 Lawang 65218 \\ *)e-mail: marsaidsaid411@ gmail.com
}

\begin{abstract}
ABSTRAK
KPekerja perkayuan atau mebel merupakan pekerja dengan resiko paparan debu, baik yang berasal dari penggergajian atau pengampelasan kayu, sehingga beresiko terkena penyakit akibat kerja berupa penyakit saluran pernafasan dengan gejala utamanya batuk. Kurangnya pengetahuan dan disiplin kerja dari para pekerja untuk menggunakan alat pengaman diri (APD) berupa, masker merupakan salah satu faktor yang mempengaruhi timbulnya penyakit saluran pernafasan dengan gejala utamanya batuk. Hal ini terjadi karena para pekerja menghirup debu penggergajian atau pengampelasan kayu dalam dosis besar. Penelitian ini bertujuan untuk mengetahui hubungan antara kebiasaan menggunakan masker dengan terjadinya batuk pada pekerja industri mebel. Desain penelitian yang digunakan adalah korelasional dengan pendekatan cross sectional. Sampel pada penelitian ini adalah para pekerja industri mebel yang berjumlah 30 orang. Pengumpulan data dengan wawancara. Hasil penelitian didapatkan bahwa $67 \%$ sering menggunakan masker, dan $33 \%$ jarang menggunakan masker. Frekuensi batuk didapatkan bahwa batuk sedang $60 \%$, batuk ringan $33 \%$, dan sisanya $7 \%$ batuk berat. Uji analisis statistik spearman rank correlation dengan $\ddot{\mathrm{U}}=0,05$ didapatkan nilai $\mathrm{p}=0,028$ artinya ada hubungan antara kebiasaan menggunakan masker dengan terjadinya batuk pada pekerja industri mebel. kesimpulannya adalah para responden mengerti tentang bahaya penyakit akibat kerja khususnya batuk, sehingga mereka bisa menjaga diri mereka sendiri dari pemaparan debu kayu. Agar kesehatan mereka tetap terpelihara, maka dianjurkan untuk selalu memakai masker saat bekerja.
\end{abstract}

Kata kunci: masker, batuk, pekerja mebel

\begin{abstract}
Lumber or furniture worker is a worker with the risk of exposure to dust, whether originating from sawing or sanding wood, so the risk of illness due to respiratory diseases such as working with the main symptoms of cough. Lack of knowledge and discipline of the workers to use safety devices themselves $(A P D)$ in the form, the mask is one factor affecting the incidence of respiratory disease with main symptoms of cough. This happens because the workers breathe in dust sawing or sanding wood in large doses. This study aims to determine the relationship between the habite of using the mask with the occurrence of cough in the furniture industry workers. The study design was cross-sectional correlational approach in this study is the furniture industry workers numbering 30 people. Data collection with interviews. The results showed that $67 \%$ frequently use masks, and 33\% less using a mask. Cough frequency found that cough was 60\%, 33\% mild cough, and the remaining 7\% severe cough. Spearman rank test statistical analysis $\ddot{U}=0.05$ correlation with $p$ value $=0.028$ means that there is a relationship between the habit of using a mask with the occurrence of cough in the furniture industry workers. Conclusion is the respondent to understand about the dangers of diseases caused by work, especially cough, so they can keep themselves from wood dust exposure. So that their health is maintained, then it is advisable to always wear a mask when working.
\end{abstract}

Keywords: masks, cough, furniture workers 


\section{LATAR BELAKANG}

Di era globalisasi menuntut perlindungan kesehatan dan keselamatan disetiap tempat kerja, termasuk di sektor informal. Di negara berkembang, sektor yang paling penting dari sektor kesehatan kerja adalah pertanian, industri kecil dan pertambangan. Dalam pelaksanaan pekerjaan sehari-hari pekerja industri mebel akan terpajan dengan resiko penyakit akibat kerja. Risiko ini bervariasi mulai dari yang paling ringan sampai yang paling berat, tergantung jenis pekerjaannya. Udara yang dihirup selain mengandung unsur oksigen, juga mengandung berbagai partikel lain. Kita mengenalnya dengan sebutan debu. Debu yang masuk kedalam saluran pernapasan akan merangsang paru dan menimbulkan mekanisme pertahanan. Dalam dosis besar, semua debu bersifat merangsang dan dapat menimbulkan reaksi batuk dan bersin. Selain batuk dan bersin reaksi tersebut dapat berupa produksi lendir berlebihan.

Penelitian yang dilakukan oleh Zilfa (2004), didapatkan $11,11 \%$ menderita asma kerja dan 6,67\% menderita asma yang diperburuk oleh debu kayu lingkungan dari 135 pekerja mebel sektor informal yang diteliti. Berdasarkan studi pendahuluan yang dilakukan peneliti pada tanggal 25 Agustus 2008 di industri mebel UD RS di Desa Karangsono Kecamatan Sukorejo Kabupaten Pasuruan didapatkan bahwa dari 5 orang pekerja, 2 orang pekerja sedang mengalami batuk. Mereka mengatakan bahwa batuk tersebut merupakan hal yang biasa. Menurut mereka ia jarang menggunakan masker, masker dipakai terutama apabila mereka sedang sakit batuk.

Dalam debu kayu terdapat biohazard dan mikroorganisme, endotoksin dari bakteri dan alergi dari jamur, akibatnya timbul gangguan kesehatan yang disebut organic dust toxic syndrome (ODTS), asma, bronkitis, extrinsic allergic alveolitis (EAA), jenis jamurnya adalah Aspergillus dan Penisillium. Standar debu kayu di lingkungan kerja menurut NIOSH adalah $1 \mathrm{mg} / \mathrm{m}^{3}$ untuk hardwood dan $5 \mathrm{mg} / \mathrm{m}^{3}$ untuk softwood untuk pekerja yang bekerja 8 jam sehari. Penelitian menunjukan bahwa walaupun kadar debu di bawah ambang batas (misalnya kurang dari $1 \mathrm{mg} / \mathrm{m}^{3}$ ), masih ditemukan gejala di mata, hidung, tenggorokan, kulit dan paru. Gangguan respirasi kronis akan menyebabkan gangguan fungsi paru. Upaya-upaya ini dilakukan tubuh guna mengeluarkan debu dari saluran pernapasan. Namun terkadang upaya pertahanan tubuh ini tidak berhasil dan mengakibatkan sumbatan pada jalan napas, otot-otot polos pada jalan napas terangsang, dan jalan napas menjadi menyempit. Lebih lanjut lagi, dapat mengakibatkan penyakit pada paru. Hal ini dikenal sebagai penyakit paru akibat pekerjaan. Faktor yang berpengaruh dalam menentukan berat ringannya keluhan batuk yang timbul diantaranya adalah adalah jumlah debu yang masuk ke dalam paru, lamanya pemaparan, jenis dan sifat dari debu serta kepekaan individual.

Penelitian yang dilakukan oleh Irfan (2003), tenaga kerja yang terpapar debu kayu mempunyai peluang 6,2 kali akan mengalami keluhan subyektif saluran pernapasan dan akan mengalami gangguan ventilasi paru sebesar 5 kali. Tenaga kerja yang perokok mempunyai peluang 4,1 kali akan mengalami keluhan subyektif saluran pernapasan dan 7,1 kali akan mengalami gangguan ventilasi paru. Tenaga kerja dengan keluhan subyektif saluran pernapasan mempunyai peluang 3,4 kali akan mengalami gangguan ventilasi paru. Salah satu cara menanggulangi terjadinya gangguan saluran pernafasan atau keracunan akibat debu hasil produksi, adalah dengan menggunakan APD. Penggunaan APD merupakan pilihan terakhir dalam melindungi kesehatan dan keselamata pekerja dari potensi bahaya. APD dilakukan setelah pengendalian teknik dan administratif tidak mungkin lagi diterapkan (Koesyanto, 2005). APD untuk mencegah agar debu tidak terhirup adalah dengan menggunakan masker, yang 
terdiri dari berbagai macam bentuk seperti masker kain kasa dan resporator setengah masker. Namun sebagian tenaga kerja merasa kurang nyaman dalam menggunakan masker. Perasaan ataupun keluhan yang dirasakan memberikan respon yang berbedabeda. Perasaan tidak nyaman itu pada akhirnya akan mengakibatkan keengganan tenaga kerja dalam menggunakannya. Pengunaan APD sebenarnya sudah diatur dalam Undang-undang No. 1 tahun 1970 tentang Keselamatan Kerja, khususnya pasal 9, 12 dan 14, yang mengatur penyediaan dan penggunaan APD di tempat kerja, baik bagi pengusaha maupun bagi tenaga kerja (Budiono, 2003). Pemakaian APD masker untuk melindungi saluran pernafasan dari paparan debu sebenarnya sangat praktis dalam pelaksanaannya. Akan tetapi, praktik di lapangan sangat sulit diterapkan, hal ini terletak pada tenaga kerja itu sendiri yang berhubungan erat dengan faktor manusia. Selain itu, aspek perilaku pekerja yang terkait dengan kedisiplinan penggunaan masker masih sangat minim (DepKes RI, 2003).

Fenomena pemakaian masker ini sangat menarik untuk dikaji lebih mendalam karena kesehatan dan keselamatan para pekerja harus lebih diutamakan. Mengingat akibat jangka panjang yang ditimbulkan apabila para pegawai pengamplasan tidak memakai masker dapat membahayakan kesehatan, maka perlu dilakukan penelitian untuk mengetahui hubungan antara kebiasaan menggunakan masker dengan terjadinya batuk pada pekerja industri mebel.

\section{METODE}

Penelitian menggunakan desain korelasional dengan pendekatan cross sectional. Sampel pada penelitian ini adalah para pekerja industri mebel. Dari populasi yang ada, semuanya dijadikan sebagai sampel penelitian yaitu 30 orang pekerja. Penelitian dilaksanakan pada tanggal 17 Nopember sampai dengan 5 Desember 2008 bertempat di Desa Karangsono Kecamatan Sukorejo Kabupaten Pasuruan.

Untuk mendapatkan data peneliti menggunakan metode wawancara. Kemudian mengelompokkan data sesuai variabel yang telah ditetapkan. Untuk kedua variabel, data yang telah terkumpul ditabulasi dan diberi skor, kemudian dijumlahkan dan dibandingkan dengan jumlah maksimal kemudian dikalikan $100 \%$, hasilnya diprosentasekan dan disajikan dalam tabel distribusi frekuensi. Variabel kebiasaan menggunakan masker dikategorikan menjadi: tidak pernah (skor 0) bila pekerja tidak pernah menggunakan masker selama bekerja di industri mebel, jarang (skor 1) bila pekerja lebih banyak tidak menggunakan masker selama bekerja di industri mebel, sering (skor 2) bila pekerja lebih banyak menggunakan masker selama bekerja di industri mebel, dan sering sekali (skor 3) bila pekerja selalu menggunakan masker selama bekerja di industri mebel. Sedangkan variabel terjadinya batuk pada pekerja dikategorikan menjadi: batuk ringan bila skornya (0-33\%), batuk sedang bila skornya (34-66\%), dan batuk berat bila skornya (67-100\%). Selanjutnya ditentukan prosentase masing-masing kategori dengan menggunakan rumus:

$$
\mathrm{P}=\underset{\mathrm{N}}{\stackrel{\mathrm{N}}{\mathrm{f}} \mathrm{x} 100 \%}
$$

Keterangan:

$\mathrm{P}=$ prosentase

" $\mathrm{f}=$ frekuensi jawaban

$\mathrm{N}=$ jumlah responden

Kemudian data uji analisa statistik dengan menggunakan spearman rank correlation dengan bantuan program SPSS dengan $\mathrm{a}=0,05$.

\section{HASIL DAN PEMBAHASAN}

\section{Hasil}


Tabel 1. Distribusi frekuensi responden berdasarkan kelompok usia, pendidikan, lama bekerja, di Desa Karangsono Kecamatan Sukorejo Kabupaten Pasuruan Tahun 2008

\begin{tabular}{|c|c|c|c|}
\hline No & Distribusi & Frekuensi (f) & Prosentase (\%) \\
\hline \multicolumn{4}{|c|}{ Kelompok usia (th): } \\
\hline 1 & $16-40$ & 20 & 66 \\
\hline 2 & $41-60$ & 10 & 34 \\
\hline 3 & $>60$ & 0 & 0 \\
\hline \multicolumn{2}{|r|}{ Jumlah } & 30 & 100 \\
\hline \multicolumn{4}{|c|}{ Tingkat pendidikan: } \\
\hline 1 & SD tidak tamat & 2 & 7 \\
\hline 2 & SD & 8 & 26 \\
\hline 3 & SLTP & 6 & 20 \\
\hline 4 & SLTA & 14 & 47 \\
\hline \multicolumn{2}{|r|}{ Jumlah } & 30 & 100 \\
\hline \multicolumn{4}{|c|}{ Lama bekerja: } \\
\hline 1 & $0-2$ tahun & 4 & 14 \\
\hline 2 & $>2$ tahun -4 tahun & 6 & 20 \\
\hline 3 & $>4$ tahun -6 tahun & 10 & 33 \\
\hline 4 & $>6$ tahun & 10 & 33 \\
\hline \multicolumn{2}{|r|}{ Jumlah } & 30 & 100 \\
\hline
\end{tabular}

Dari tabel 1 didapatkan hasil distribusi frekuensi responden berdasarkan kelompok usia 16-40 tahun sebanyak 20 responden $(66 \%)$, berdasarkan tingkat pendidikan didapatkan responden yang tamat SLTA sebanyak 14 responden $(47 \%)$ dan berdasarkan lama bekerja > 4-6 tahun sebanyak dan > 6 tahun masing-masing sebanyak 10 orang $(33 \%)$.

Tabel 2. Distribusi frekuensi kebiasaan menggunakan masker, dan terjadinya batuk pada pekerja industri mebel di Desa Karangsono Kecamatan Sukorejo Kabupaten Pasuruan Tahun 2008

\begin{tabular}{llcc}
\hline No & \multicolumn{1}{c}{ Distribusi } & Frekuensi (f) & Prosentase (\%) \\
\hline & Kebiasaan menggunakan masker: & & \\
\hline 1 & Tidak Pernah & 0 & 0 \\
2 & Jarang & 10 & 33 \\
3 & Sering & 20 & 67 \\
4 & Sering sekali & 0 & 0 \\
\hline \multicolumn{2}{c}{ Jumlah } & 30 & 100 \\
\hline \multicolumn{2}{l}{ Terjadinya batuk: } & & 33 \\
\hline 1 & Batuk ringan & 10 & 60 \\
3 & Batuk sedang & 18 & 7 \\
\hline & Batuk berat & 2 & 100 \\
\hline
\end{tabular}

Dari tabel 2 didapatkan hasil distribusi frekuensi responden berdasarkan kebiasaan menggunakan masker bahwa sebanyak 20 responden $(67 \%)$ sering menggunakan masker selama mereka bekerja di industri mebel dan berdasarkan terjadinya batuk didapatkan bahwa terjadinya batuk pada pekerja dalam kategori batuk sedang sebanyak 18 responden $(60 \%)$.

Tabel 3. Tabulasi silang antara kebiasaan menggunakan masker dengan terjadinya batuk pada pekerja industri mebel di Desa Karangsono Kecamatan Sukorejo Kabupaten Pasuruan Tahun 2008

\begin{tabular}{lccccccc}
\hline No & $\begin{array}{c}\text { Terjadinya } \\
\text { batuk }\end{array}$ & \multicolumn{2}{c}{ Kebiasaan penggunaan masker } & Total & $\%$ \\
\hline & & Jarang & $\%$ & Sering & $\%$ & & \\
\hline 1 & Batuk berat & 2 & 7 & 0 & 0 & 2 & 7 \\
\hline
\end{tabular}




\begin{tabular}{clcccccc}
\hline 2 & Batuk sedang & 8 & 27 & 10 & 33 & 18 & 60 \\
3 & Batuk ringan & 0 & 0 & 10 & 33 & 10 & 33 \\
\hline & Total & 10 & 34 & 20 & 66 & 30 & 100 \\
\hline
\end{tabular}

Dari tabel 3 didapatkan hasil tabulasi silang antara kebiasaan menggunakan masker dengan terjadinya batuk pada pekerja industri mebel yaitu batuk berat dan jarang menggunakan masker sebanyak 7\%, batuk sedang dan jarang menggunakan masker sebanyak $27 \%$, batuk sedang dan sering menggunakan masker sebanyak $33 \%$, batuk ringan dan sering menggunakan masker sebanyak $33 \%$.

Tabel 4. Hasil uji analisa statistik spearman rank correlation

\begin{tabular}{ccc}
\hline & Kebiasaan Penggunaan masker & Terjadinya batuk \\
\hline Correlation Coefficient & 1,000 &, $567\left(^{*}\right)$ \\
Sig. (2-tailed) &, 028 &, 028 \\
$\mathbf{N}$ & 30 & 30 \\
\hline
\end{tabular}

Keterangan:

* Correlation is significant at the 0,05 level (2-tailed).

Dari tabel 4 didapatkan hasil uji statistik spearman rank correlation dengan a $=0,05$ didapatkan nilai $\mathrm{p}=0,028<0,05$ yang berarti bahwa H0 ditolak dan H1 diterima artinya ada hubungan antara kebiasaan menggunakan masker dengan terjadinya batuk pada pekerja industri mebel di Desa Karangsono Kecamatan Sukorejo kabupaten Pasuruan.

\section{Pembahasan}

\section{Kebiasaan Menggunakan Masker Pada Pekerja Industri Mebel}

Berdasarkan hasil penelitian pada tabel 2 didapatkan bahwa sebanyak 20 responden (67\%) sering menggunakan masker selama mereka bekerja di industri mebel. Hal ini berarti bahwa para pekerja dalam sehariharinya lebih banyak menggunakan masker dari pada tidak menggunakan masker selama bekerja di industri mebel, sedangkan sisanya yaitu 10 responden (33\%) jarang menggunakan masker selama mereka bekerja di industri mebel.

Dari hasil wawancara peneliti kepada para pekerja bahwa alasan mereka kurang disiplin dalam menggunakan masker pada saat bekerja antara lain adalah rasa enggan, tidak nyaman, rasa pengap ataupun kurang bisa bernapas dengan lega bila menggunakan masker. Jenis masker yang disediakan oleh perusahaan yaitu masker sekali pakai yang terbuat dari kain kasa dengan tali di bagian samping. Beberapa pekerja yang lain mengatakan bahwa alasan mereka enggan menggunakan masker diantaranya yaitu mengganggu komunikasi dengan temannya. Menurut Santoso (2004) beberapa masalah yang dapat mempengaruhi pekerja tidak disiplin menggunakan masker pada saat bekerja antara lain adalah karena panas atau sesak saat menggunakan masker, tidak nyaman, kesulitan berkomunikasi, rasa berat serta tidak ada sanksi bila tidak menggunakan. Para pekerja perkayuan atau pekerja mebel adalah pekerja yang beresiko mengalami penyakit akibat kerja akibat pemajanan yang lama terhadap sumber alergen yaitu debu kayu. Pencegahan masalah ini bisa dilakukan dengan tindakan sederhana seperti menggunakan masker. Penggunakan alat pengaman diri (APD) berupa masker harus tetap dilaksanakan untuk meminimalkan paparan debu penggergajian dan pengampelasan kayu kepada para pekerja pada saat mereka bekerja. 


\section{Terjadinya Batuk Pada Pekerja Industri Mebel}

Berdasarkan hasil penelitian pada tabel 2 didapatkan bahwa terjadinya batuk pada pekerja industri mebel dalam kategori batuk sedang sebanyak $60 \%$, kategori batuk ringan sebanyak $33 \%$, dan sisanya $7 \%$ dalam kategori batuk berat.

Batuk adalah suatu mekanisme perlindungan berupa reflek fisiologis yang bertujuan untuk mengeluarkan dan membersihkan saluran pernapasan dari benda asing yang merangsang terjadinya reflek tersebut. Batuk terjadi karena rangsangan tertentu, misalnya debu di reseptor batuk (hidung, saluran pernafasan, bahkan telinga). Kemudian reseptor akan mengalirkan lewat syaraf ke pusat batuk yang berada di otak. Di sini akan memberi sinyal kepada otot-otot tubuh untuk mengeluarkan benda asing tadi, hingga terjadilah batuk. Selain itu debu yang masuk ke dalam saluran pernapasan akan merangsang paru dan menimbulkan mekanisme pertahanan. Hal ini akan nampak sebagai batuk, bersin, ataupun pengeluaran lendir (dahak). Upaya-upaya ini dilakukan tubuh guna mengeluarkan debu dari saluran napas. Namun terkadang upaya pertahanan tubuh ini tidak berhasil dan mengakibatkan sumbatan pada jalan napas, otot-otot polos pada jalan napas terangsang, dan jalan napas menjadi menyempit. Lebih lanjut lagi, dapat mengakibatkan penyakit pada paru. Hal ini dikenal sebagai penyakit paru akibat pekerjaan.

\section{Hubungan Antara Kebiasaan Menggunakan Masker Dengan Terjadinya Batuk Pada Pekerja Industri Mebel Di Desa Karangsono Kecamatan Sukorejo Kabupaten Pasuruan}

Berdasarkan hasil uji analisa statistik spearman rank correlation pada tabel 4 didapatkan bahwa dengan a $=0,05$ didapatkan nilai $\mathrm{p}=0,028<0,05$ yang berarti ada hubungan antara kebiasaan menggunakan masker dengan terjadinya batuk pada pekerja industri mebel di Desa Karangsono Kecamatan Sukorejo Kabupaten Pasuruan. Hal ini dapat dilihat dari hasil penelitian pada tabel 3 didapatkan bahwa 34\% pekerja yang jarang menggunakan masker selama bekerja mengalami batuk berat sebanyak $7 \%$ sedangkan $27 \%$ mengalami batuk sedang.

Debu penggergajian atau pengampelasan kayu menyebabkan reflek batuk atau spasme laring. Jika debu ini menembus ke dalam paru-paru dapat terjadi bronkitis toksik atau asma. Para pekerja mebel menjadi toleran terhadap paparan iritan berkadar rendah dengan meningkatkan sekresi mukus. Partikel-partikel debu dan aerosol yang berdiameter lebih dari 15 mikron tersaring ke luar pada saluran pernapasan bagian atas. Partikel 5-15 mikron tertangkap pada mukosa saluran yang lebih rendah dan kembali disapu ke laring oleh kerja mukosilier, selanjutnyaa ditelan. Bila partikel ini mengiritasi saluran napas atau melepaskan zat-zat yang merangsang respon imun, dapat timbul penyakit pernapasan seperti bronkitis. Partikel-partikel berdiameter antara 0,5-5 mikron (debu yang ikut dengan pernapasan) dapat melewati sistem pembersihan mukosilier dan masuk ke dalam saluran pernapasan terminal serta alveoli. Selanjutnya debu ini akan dikumpulkan oleh sel-sel scavenger (makrofag) dan diantarkan kembali ke sistem mukosilier atau sistem limfatik. Partikel-partikel berdiameter kurang dari 0,5 mikron kemungkinan tetap mengambang dalam udara dan tidak diretensi. Partikel-partikel panjang atau serat yang diameternya kurang dari 3 mikron dengan panjang sampai 100 mikron dapat mencapai saluran napas terminal, namun tidak dapat dibersihkan oleh makrofag, akan tetapi mungkin pula ditelan lebih dari 1 makrofag (WHO, 1995). Menurut WHO (1995) disebutkan bahwa penggunaan alat pengaman diri (APD) dapat meminimalkan dampak timbulnya penyakit akibat kerja. 
Dalam hal ini penggunaan masker sebagai alat pengaman diri pada saat bekerja, dapat mengurangi paparan debu dari hasil pengampelasan, penggergajian atau proses penghalusan kayu. Ukuran debu pengamplasan adalah partikel kecil yang dihasilkan oleh proses penghalusan mekanis. Ukuran debu pengamplasan antara 1-4 mikron. (DepKes RI, 2003). Ukuran debu sisa proses pengamplasan dapat ditangkap atau dicegah dengan menggunakan masker, minimal masker yang terbuat dari kain kasa dan akan lebih baik lagi menggunakan respirator setengah masker.

Beberapa faktor pengganggu yang tidak diteliti pada penelitian ini dan berpengaruh terhadap terjadinya batuk pada pekerja mebel antara lain adalah penyakit yang menyertai serta pengobatannya, riwayat pemajanan terdahulu terhadap bahan alergen debu, riwayat perokok dan kadar alergen debu yang berbeda-beda, serta lama paparan bahan alergen. Selain itu faktor usia juga mempengaruhi daya tahan tubuh dari masingmasing individu dalam mempertahankan dirinya terhadap bahan alergen debu yang masuk (Harington, 2005).

\section{KESIMPULAN DAN SARAN}

Berdasarkan hasil penelitian yang telah dilakukan bahwa kebiasaan menggunakan masker pada pekerja industri mebel di Desa Karangsono Kecamatan Sukorejo Kabupaten Pasuruan didapatkan bahwa sebagian besar responden sering menggunakan masker selama mereka bekerja di industri mebel, sedangkan sisanya jarang menggunakan masker selama mereka bekerja di industri mebel. Terjadinya batuk pada pekerja industri mebel di Desa Karangsono Kecamatan Sukorejo Kabupaten Pasuruan didapatkan bahwa sebagian besar terjadinya batuk pada pekerja industri mebel dalam kategori batuk ringan. Berdasarkan hasil uji statistik menunjukkan bahwa ada hubungan antara kebiasaan menggunakan masker dengan terjadinya batuk pada pekerja industri mebel di Desa Karangsono Kecamatan Sukorejo Kabupaten Pasuruan.

Saran bagi responden diharapkan dapat mengerti tentang bahaya penyakit akibat kerja khususnya batuk, sehingga mereka bisa menjaga diri mereka sendiri dari pemaparan debu kayu lebih lanjut dengan selalu memakai masker saat bekerja. Bagi institusi pendidikan diharapkan laporan hasil penelitian ini dapat digunakan untuk meningkatkan pengetahuan tentang penyakit akibat kerja khususnya hubungan antara kebiasaan menggunakan masker dengan terjadinya batuk pada pekerja industri mebel. Bagi peneliti selajutnya diharapkan laporan hasil penelitian ini dapat digunakan sebagai bahan informasi bagi peneliti selanjutnya untuk mengembangkan penelitian-penelitian lainnya yang terkait dengan penyakit akibat kerja atau faktorfaktor lain yang diduga dapat mempengaruhi kesehatan maupun produktifitas kerja. Bagi lahan penelitian diharapkan kepada pemilik industri mebel untuk lebih meningkatkan pengawasan terhadap kedisiplinan penggunaan masker dan mengadakan kerja sama dengan petugas kesehatan untuk mengadakan penyuluhan atau pemeriksaan kesehatan secara berkala terhadap para pekerja sebagai upaya preventif dan deteksi dini penyakit akibat kerja.

\section{DAFTAR PUSTAKA}

Adhitya, D. 2007. Faktor-Faktor yang Berhubungan dengan Penggunaan Masker pada para Pekerja Pengamplasan di Perusahaan Meubel CV Permata 7 Wonogiri. http:// digilib.unnes.ac.id/gsdl/collect/skripsi/ archives/HASH013d.dir/doc.pdf. Diakses tanggal 26 Juli 2010 pukul 10.00 WIB.

Anies. 2005. Penyakit Akibat Kerja. Jakarta: PT. Elex Media Komputindo.

Arikunto, S. 2002. Prosedur Penelitian. Ed. Revisi V. Jakarta: PT. Rineka Cipta. 
Arwin, B. 2008. Danger in the Woods. http:/ / w w w. c e f e d.in $\mathrm{fol}$ index.php?category_id=4\&parent_id=4. Diakses tanggal 12 Mei 2008 pukul 11.00 WIB.

Damayanti, T., et.al. 2007. Association Between Babit of Using Respirator and Respiratory Symptoms, Lung Functions and Chest x-ray Due to Cement Dust Exposure. www.mki.idionline.org/ index.php?uPage=mki.mki_dl\&smod. Diakses tanggal 26 Juli 2010 pukul 10.00 WIB.

Harrington, J.M., \& Gilln, F.S. 2005. Buku Saku Kesehatan Kerja. Ed. 3. Jakarta: EGC.

Haryanto, 2008. Hubungan Antara Masa Kerja, Merokok, Perilaku Pemakaian Masker dengan Kejadian Suspek dan Infeksi TBC Paru pada Petugas Kesehatan Balai Pencegahan dan Pengobatan Penyakit Paru Semarang. http://eprints.undip.ac.id/6860/. Diakses tanggal 26 Juli 2010 pukul 11.00 WIB.

Muslikatul Mila S, 2006. Hubungan Antara Masa Kerja, Pemakaian Alat Pelindung Pernafasan (Masker) dengan Kapaasitas Fungsi Paru pada Tenaga Kerja Bagian Pengamplasan PT. Accent House Pecanggaan Jepara. http://digilib.unnes.ac.id/gsdl/collect/ skripsi/archives/HASH14d7/697cf7. Diakses tanggal 26 Juli 2010 pukul 10.00 WIB.

Notoatmodjo, S. 2001. Metodologi Penelitian Kesehatan. Jakarta: PT. Rineka Cipta. Nursalam. 2001. Pendekatan Praktis Metodologi Riset Keperawatan. Jakarta: $\mathrm{CV}$. Indofomedia.

Ramaddan, 2008. Gambaran Perilaku Pemakaian Masker dan Pengukuran Kadar Debu pada Pekerja bagian Bongkar Muat Karet Kering Instalasi Belawan PTPN III Tahun 2008. http:// repository.usu.ac.id/bitstream/ 123456789/14720/1/09E01024.pdf. Diakses tanggal 26 Juli 2010 pukul 12.00 WIB.
Santoso, G. 2004. Manajemen Keselamatan dan Kesehatan Kerja. Jakarta: Prestasi Pustaka Publiser.

Soeparman. 1999. Prinsip-Prinsip Ilmu Penyakit Dalam. Volume 1. Jakarta: EGC.

WHO. 1995. Deteksi Dini Penyakit Akibat Kerja. Jakarta: EGC.

Zilfa, Y. 2002. http://www.webmd.com edited by Scientific Medicastore. Diakses tanggal 03 Maret 2008 pukul 9.00 WIB.

Zuliastanti T, 2008. Pengaruh pendidikan kesehatan tentang penggunaan masker terhadap tingkat pengetahuan dan sikap pekerja pengamplasan kayu di desa Rengging Pecangaan Jepara. http:// etd.eprints.ums.ac.id/2694/1/ J210040025.pdf. Diakses tanggal 26 Juli 2010 pukul 10.00 WIB. 